\title{
A General Overview on Occupational Health and Safety and Occupational Disease Subjects
}

\author{
İzzet Fidancı", Onur Ozturk \\ Atakum Community Health Center, Samsun, Turkey
}

Email address:

izzetfidanci@gmail.com (İ. Fidanc1)

\section{To cite this article:}

İzzet Fidanc1, Onur Ozturk. A General Overview on Occupational Health and Safety and Occupational Disease Subjects. Journal of Family Medicine and Health Care. Vol. 1, No. 1, 2015, pp. 16-20. doi: 10.11648/j.jfmhc.20150101.15

\begin{abstract}
Unhealthy factors and working conditions in working environment cause many health problems. While employees have rights and related tasks to work in a healthy and secure environment, employers have the liability to provide this environment and services. Every year a substantial amount of people die or become handicapped due to easily preventable occupational accidents and diseases which should legally be prevented. This compilation was prepared by studying occupational health and safety subjects, frequency of occupational diseases and laws made in the world in recent years.
\end{abstract}

Keywords: Occupational Health and Safety, Occupational Diseases, Occupational Accidents

\section{Introduction}

According to the definition by International Labour Organization (ILO) and World Health Organization (WHO), labour health is the work carried out for keeping, continuing and developing body, mental and social well-being of individuals working in all occupations at utmost level. Occupational health is bringing the well-being of workers, partners and children to the uppermost level, developing living conditions, protecting them from unhealthy conditions both in working and living environments, making them work in suitable jobs for their talents and providing a healthy and high-quality production with healthy people and being protected from all kinds of stress factors as far as possible $(1,2)$.

Working life is the most important factor determining the body, mental and social well-being of employee. Occupational health and safety is on the agenda of developed industrial countries as well as developing countries with its constantly developing and changing dynamic structure.

Every year a substantial amount of people die or become handicapped due to easily preventable occupational accidents and diseases which should legally be prevented.

According to numbers reported by ILO, nearly 6,000 people die due to occupational accidents or diseases every day. A total of 350.000 people die due to occupational accidents and 1.700 .000 people die from occupational diseases every year. Every year 2700 million occupational accidents take place and 160 million people have occupational diseases. It is stated that every year 438.000 workers die because of toxic materials and $10 \%$ of the skin cancers in the world is due to contact with toxic materials at work. It is estimated that 100.000 people die because of asbestos every year. Besides since 1970's, asbestos manufacturing is continuously decreasing in the world. But the risk continues for those who had contact with asbestos before $(1,3)$.

\section{Occupational Health and Safety}

Occupational accidents and occupational diseases are among the most important problem areas of working life. International Labour Organization estimates that 358,000 work accidents involving death, 337 involving injury occurred in the world in 2003 and 1,95 million people died because of occupational diseases $(4,5)$.

Income losses of the people left behind in case of death and of the injured person and family in case of mutilation reach enormous dimensions. Economic cost of occupational accidents and diseases reach $5 \%$ of natural incomes in the world $(4,5)$. Social protection is a broad concept covering the countermeasures for occupational accidents and occupational diseases and compensation systems for income loss and expenditure increases of the injured person and family after the accident or disease. It is observed that the first efforts for constituting a modern social security system in the world are for the compensation of the damage caused by occupational accident and diseases. In developing countries the social 
insurance systems for occupational accidents and diseases were started after World War II. But still a significant ratio of the employees in developing countries is outside this insurance. Occupational health and safety legislation is effectively applied in highly developed countries(4).

\section{Occupational Accidents and Diseases}

Globalization is an economical, social, cultural and political process in which the capital can expand in all countries without a boundary. In the mentioned period, developed countries secure technological superiority, lead profitable activities and make the transnational transfer of the capital easier and secure the capital. Developing countries are making the capital inflow easier by providing freedom in goods and financial markets, forming free zones, applying high interests, privatizing, suppressing payments in order to increase capital profits $(4,6)$.

Globalization effects developed and developing countries in different scales in occupational health and safety fields $(4,7)$. While the rate of occupational accidents involving death is low in developed countries (Europe, USA and Asia Pacific areas), it is observed that the rate of occupational accidents involving death is high in developing countries. Globalization is also one of the main factors highly effective on occupational health and safety legislation and application.

Particularly in difficult and dangerous jobs, the production moves from central countries to the surrounding countries globally. While secure labour force mainly works in research and development, marketing activities in central countries, the hard and dangerous part of manufacturing is fulfilled by unsecured, low-paid employees in surrounding countries $(4,8)$. In globalization period, the increased capital flow increases the negotiation power of public institutions and enterprises. States are obliged to draw foreign capital and sacrifice in order to make this consistent $(4,9)$. Investors in global markets immigrate to countries with low labour costs in order to increase competition forces and increase their profits benefiting from informal labour forms (10).

Together with globalization, while developing countries take a lower share from global national income, labour force in these countries works in insecure and poor quality jobs. Ancient technologies prohibited or prevented in developed countries cause negative working and living conditions in developing countries. During globalization, enterprises buy service directly or externally and assign a part of the main job to subcontractors. Small and medium-sized enterprises have difficulty in taking occupational health and safety measures due to their weak financial structures. Company spin-off would be encountered less with globalization. The mentioned situation would require more attention on occupational health and safety subjects by small-sized enterprises and self-employed people. Problems such as lack of national policies on occupational health and safety and occupational health safety legislation, inadequate education, inability to spare a satisfactory budget to occupational health safety and inadequacy of staff for including small-sized enterprises and informal sector should be solved in developing countries $(4,7,11,12,13)$.

Globalization and economic crisis adversely effect working environment quality. Economic crisis cause a decline also in occupational health and safety services. Providing occupational health and safety services from external sources (suppliers) is becoming more common in Europe. Many institutions providing education and making research on occupational health and safety are getting smaller or closed due to institutional budgetary savings. Acceptance level for occupational health and safety services increasing productivity and prosperity is very low in many sectors $(4,14)$.

Occupational diseases are another important problem. Many workers are unaware of the fact that they have occupational diseases. Since occupational diseases also occur after leaving the job, employees and doctors generally don't recognize and evaluate them as normal diseases. If the occupational disease occurs after leaving work, during the occupational and social safety legislation investigation of the subject, shutdown workplace or inability to determine occupational health and safety conditions or execution conditions in the working period of the employee also make the determination of occupational diseases harder $(4,15)$.

A globally accepted occupational disease list is not available. Countries determine the standards evaluating which events should be accepted as occupational diseases considering their own conditions. On the other hand, as there is no certain proof showing that a disease is occupational in some cases, lists showing occupational diseases were prepared in order to prevent arguments and if an employee worked in a related job, the disease was accepted occupational.

When the examples are considered, although employees who worked in denim sandblasting job for years demand constant incapacity income, they couldn't gain social insurance due to uninsured employment, difficulties in determining occupational disease, etc. Agricultural labourers working without social security cause inability to treat the diseases most of the time and compensate income losses of the employees $(12,16)$.

Occupational diseases are completely preventable diseases. There are cases effecting not only one factor, but many factors. Nutrition, individual sensitivity or variations, medicine used, smoking and drinking habits, fatness, etc. can be named among them. Occupational diseases effect family and social life. Specific organization and regulations are required in order to diagnose occupational diseases. The reason is the fact that occupational diseases can only be diagnosed if they are searched for consciously. Occupational diseases have different, distinctive diagnosis and scanning methods from other diseases. Occupational diseases can be diagnosed without any complaint of workers with periodical environment measurement and medical examinations required by legislation and necessary precautions can be taken. Informing and providing awareness among employers and employees on occupational diseases are important. 
Occupational disease diagnosis provides early diagnosis chance to close colleagues of the employee diagnosed with the disease. Since occupational disease diagnosis brings "indemnity", "high incapacity fee", "investment for developing working environment" and "criminal liability", a mistake such as hiding can be made $(16,17)$.

When it is verified that a disease is related to occupational exposure legally and medically, it is defined as occupational disease. On the other hand determining this relation is not always so easy. Most of occupational diseases occur due to multi-factored interaction. Work and disease relationship is defined in three categories:

1. Occupational Diseases; Occupational disease is diagnosed when a unique and strong occupational relation occurring due to one factor is determined.

2. Work Related Diseases; These are diseases which have a complicated aetiology in which many factors are mutually observed, working environment may have a role and different risks occur together.

3. Diseases Affecting Working Populations; These are diseases occurring more with occupational harmful factors although not related to work. Two important criteria on diagnosing occupational disease are presence of factor-exposure relationship between a certain working environment and/or activity and a certain disease and higher occurrence of diagnosed disease in mentioned occupation workers compared to public average. In order to determine factor-exposure relationship in a more definite way, clinical and pathological diagnosis, occupational anamnesis and occupation analysis and epidemiological data stating the disease and factor relationship are useful.

Definitive criteria to add a disease to international occupational disease list are mentioned below:

- Strong and scientifically proven exposure and influence relationship;

- Disease occurring in certain jobs or working areas,

- A strong relationship between the number of exposed workers and severity of risk,

- Disease enlisted in international occupational disease list of many countries.

Epidemiological studies and researches made in recent years on occupational disease increased information and intervention possibilities on occupational diseases. Diagnosing an occupational disease is a rather complicated process and with the medical diagnosis and measurement results, causality connection is stronger. Indemnity system changes between countries. ILO Occupational Diseases List (Contract No 121 and recommendation no R194) is the basic document on developing and motivating the formation and protection of occupational diseases policy of member countries. Occupational diseases are completely preventable diseases and they have a special and important place in public health and country health policies. In the light of the information received, the protection measures are varied and developed and as a result occupational disease occurrence rate in countries which can take prevention and protection measures adequately and continuously decreases $(13,17)$.

Occupational diseases are grouped under three categories in ILO Occupational Diseases List:

1. Occupational diseases which occur with agents (physical, chemical and biological),

2. Occupational diseases of target organ and systems (respiratory, skin, skeletal muscle),

3. Occupational cancers.

Occupational diseases can be classified according to the causing factors(17):

1. Chemical sourced occupational diseases

1.1. Heavy metals

1.2. Solvents

1.3. Gases

2. Physical sourced occupational diseases

2.1. Noise and vibration

2.2. Working under high and low pressure

2.3. Working in cold and hot environment

2.4. Dusts

2.5. Radiation

3. Biological occupational diseases

3.1. Bacteria sourced ones

3.2. Virus sourced ones

3.3. Biotechnological ones.

4. Psychological occupational diseases

5. Occupational diseases based on ergonomic negligence.

Many occupational diseases may be diagnosed in scope of main occupational health services. But in many of them specialized occupational medical clinics should be applied. In both cases a special plan for diagnosis is followed:

- Defining the exposure which may cause the disease,

- Examining clinical findings known to be related to special exposure,

- Excluding non-occupational factors as a possible reason of disease,

- Result about the presence and lack of occupational disease (diagnosis),

- Forming suggestions for preventing precautions at workplace,

- Informing authorities about occupational diseases.

Diagnosis of work related diseases doesn't have a certain legal status in terms of indemnity but may have an important effect on preventing and control measures. There are a few diseases with pathognomonic clinical and laboratory findings among occupational diseases. As in anaemia related to benzene intoxication, peripheral neuritis seen in acrylamide intoxication, byssinosis related bronchitis, asbestosis related fibrosis, berylliosis granuloma or silicosis nodulation samples, satisfactory findings for etiological agent cannot be reached from clinical and laboratory findings in many occupational diseases and the main factor cannot be determined. In addition to clinical findings, individual exposure information may diagnose the disease. So occupation and exposure story of the employee is of vital importance in occupational disease diagnosis(17).

Laboratory tests used in occupational disease diagnosis may be separated to five groups: 
1. General health evaluation: blood count, lung graphy, ECG, complete urine analysis.

2. Non-specific test for exposure: average corpuscular volume, average corpuscular haemoglobin concentration, eosinophil, liver enzymes, respiration function test.

3. Tests for exposed agent and metabolites: hippuric acid in urine in toluene exposure, lead analysis in blood in inorganic lead poisoning, etc.

4. Genetic and allergy tests: serum alpha 1 antitrypsin deficiency in chronic obstructive pulmonary diseases, glucose 6-phosphate dehydrogenase deficiency in haemolytic chemicals sensitivity, IgE, IgG test in organic material hyper sensitivities, etc.

5. Chromosomal changes: Some physical and chemical agent exposures may make chromosomal changes(17).

Doctor at workplace should provide information on legal rights and illness to the person diagnosed with occupational disease, provide psychological support and "protection". In proportion to the employee-employer relationship until that day, the person who was diagnosed with an occupational disease may have psychological reactions such as unhidden hostility, anger and depression because of the decision for or against continuing to work and may think that the employer caused the occupational disease which is a totally preventable situation(17).

Occupational disease is an insurance definition in medical and legal terms. This definition proves that occupational risks are not managed by employer and the employee had loss of function or disease for this reason. Because of all these reasons, health units and teams which would diagnose occupational illness should be well educated on the subject and have control over the legal process.

\section{Results and Recommendations}

Hundreds of thousands of people die every year due to occupational accidents and occupational diseases in the world. Preventing occupational accidents and diseases is certainly cheaper than indemnification. Social security on occupational accident and diseases can be examined under two main titles. The first is occupational health and security measures for removing the risks before an occasional accident and disease takes place and the second is social security services which indemnify the income loss and/or expenditure increases of the employee or family after the occupational accident and disease takes place(4).

It is known that the real number of occupational accidents is much above the formal records. It is observed that occupational accidents increase in Asia especially with the effect of globalization and industrialization in developing countries. In addition legislation and controls on occupational health and security is not satisfactory in Asia, mainly in China and India. Occupational accidents and diseases concentrate on small and medium scale jobs where hard and dangerous work is done. It is also observed that the scope of programs including the indemnification of employee damage caused after an occupational accident or disease takes place is limited in developing countries. Even though the social security programs for occupational accidents and diseases provide satisfactory protection, lack of social security continues due to the limited informal sector and operational content common in developing countries. On the other hand while deaths caused by occupational accidents decrease in developing countries, there is an increase in the number of occupation related diseases caused by reasons such as obesity, stress, etc $(4,12)$.

Applying occupational health and security rules in law, legislation and regulation level in order to prevent occupational accidents and diseases would be one of the most important steps in social protection.

Both compulsory social security coverage widening and unregistered employment lowering are necessary in order to actively indemnify income loses and expenditure increases of the insurance holder or beneficiaries after the accident or occupational disease. No matter how perfect the laws are, the application level would determine their effect on social protection.

\section{References}

[1] Yardım N, Çipil Z, Vardar C, Mollahaliloğlu S. Mortality Rates Due to Occupational Accidents and Diseases Between 2000-2005 in Turkey. Dicle Medical Journal 2007. 34(4): 264-271.

[2] Önal A. E. Türkiye'de İş Sağlığı, İstanbul Ünv. Tıp Fak. Halk Sağlığı Anabilim Dalı Seminer Notları, 2006, İstanbul. www.publichealth.pitt.edu/supercourse/SupercoursePPT/1201 1-13001/12051.ppt

[3] Nisan Dünya İş Sağlığı ve Güvenliği Günü Türkiye Raporu, Sosyal Haklar Derneği, 2007. www.sosyalhaklar.org

[4] Karadeniz O. Dünya'da ve Türkiye'de İş Kazaları ve Meslek Hastalıkları ve Sosyal Koruma Yetersizliği. Çalışma ve Toplum 2012(3): 15-75.

[5] ILO (2009), ILO standards on occupational safety and health Promoting a safe and healthy working environment, General Survey concerning the Occupational Safety and Health Convention, 1981 (No. 155), the Occupational Safety and Health Recommendation, 1981 (No. 164), and the Protocol of 2002 to the Occupational Safety and Health Convention, 1981, International Labour Conference, 98th Session, 2009. Report III (Part 1B). Third item on the agenda: Information and reports on the application of Conventions and Recommendations. Report of theCommittee of Experts on the Application of Conventions and Recommendations(articles 19, 22 and 35 of the Constitution), http://www.ilo.org/ilc/ILCSessions/98thSession/Reportssubmi ttedtotheConference/WCMS_103485/lag--en/index.htm (Erişim Tarihi:01.03.2012)

[6] Koray, Meryem (2001), Küreselleşme Süresci ve Ulus Devlet, Ekonomi, Siyaset Tartışmaları, Küreselleşme ve Ulus- Devlet, Yıldız Teknik Üniversitesi, Stratejik Araştırmalar Merkezi Yayını.

[7] Rantanen, Jorma. Grand Challenges for Occupational Health from Globalization Journal of Occupational Safety and Health 2010: 18: 167-171. 
[8] Erdut, Zeki. Rekabetin İşgücü Piyasasına Etkisi, Türk Ağır Sanayi ve Hizmet Sektörü Kamu İşverenleri Sendikası, (TÜHİS), 1998 Yayın No:29.

[9] Erdut, Zeki, (2004), Liberal Ekonomi Politikaları ve Sosyal Politika, Çalışma ve Toplum Dergisi, S:2, ss.11-37.

[10] Erdut, Zeki.Enformel İstihdamın Ekonomik, Sosyal ve Siyasal Etkileri, Çalışma ve Toplum Dergisi 2007, S:12, ss.53-82.

[11] Loewenson Rene. Globalization and occupational health: a perspective from southern Africa, Bulletin of the World Health Organization, 2001, 79 ss.863-868.

[12] Yılmaz, Fatih. Küreselleşme sürecinde gelişmekte olan ülkelerde ve Türkiye'de iş sağlığı ve güvenliğii. Uluslararası İnsan Bilimleri Dergisi 2009 6:1. http://www.insanbilimleri.com, (date:02.06.2012).

[13] Önal, Burhan. Küreselleşmenin İş Sağlığına Etkisi, Uluslararas1 26. İş Sağlı̆̆ı ve Güvenliği Kongresinden
İzlenimler, Türk Tabipleri Birliği,Mesleki Sağlık ve Güvenlik Dergisi 2001, January, ss.8-12.

[14] GAGLIARDI1 Diana, Alessandro MARINACCIO1,Antonio VALENTI1, Sergio IAVICOLI1. Occupational Safety and Health in Europe: Lessons from the Past, Challenges and Opportunities for the Future, Industrial Health, 50, ss.7-11.

[15] Karadeniz O. Occupational Diseases in Turkey, Conference on Occupational Health and Safety Economics. Building a Repository of Occupational Well-being Economics Research,27-30 April 2011,Sinaia, Romania.

[16] Yıldırak, Nurettin, Bülent GÜLÇUBUK, Sema GÜN, Emine OLHAN, Mehmet KILIÇ, (2003), Türkiye'de Gezici ve Geçici Kadın Tarım İşçilerin Çalışma Yaşam ve Koşulları ve Sorunları, Tarım-İş Sendikası yayını: Yayın No:2003/4.

[17] Meslek Hastalıkları Rehberi. Çalışma ve Sosyal Güvenlik Bakanlığı, İş Sağglığı ve Güvenliği Genel Müdürlüğü (İSGGM) November 2011, Ankara. 